\title{
Understanding Regional Economic Growth in India
}

Jeffrey D. Sachs, Nirupam Bajpai and Ananthi

Ramiah

CID Working Paper No. 88

March 2002

(C) Copyright 2002 Jeffrey D. Sachs, Nirupam Bajpai, Ananthi Ramiah and the President and Fellows of Harvard College

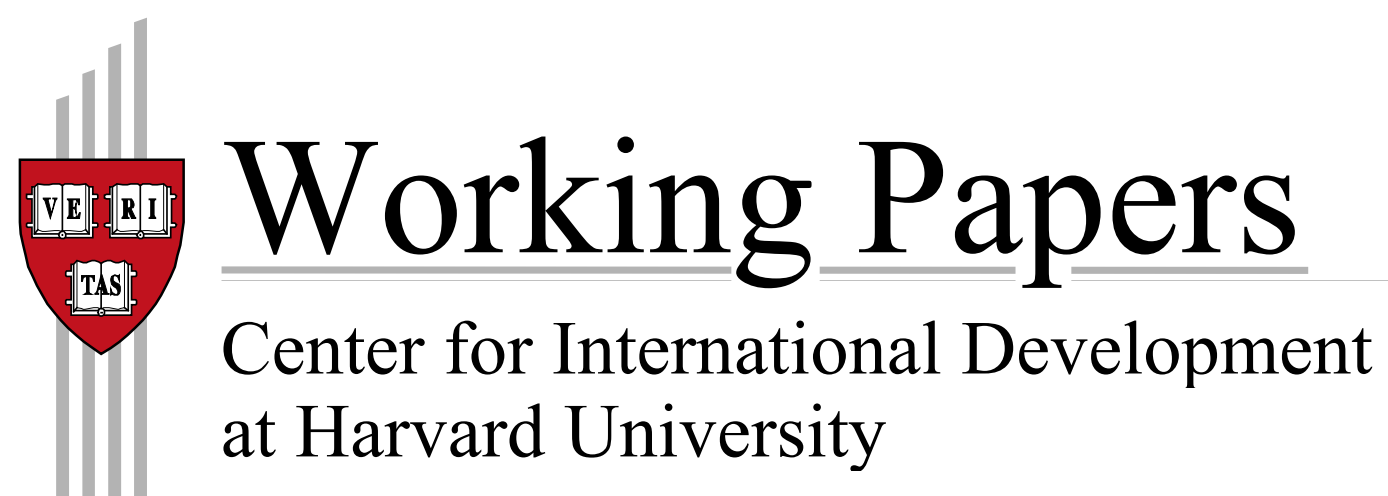




\title{
Understanding Regional Economic Growth in India
}

\author{
Jeffrey D. Sachs \\ Center for International Development (CID) \\ Harvard University \\ Jeffrey_Sachs@harvard.edu
}

\section{Nirupam Bajpai}

Center for International Development (CID)

Harvard University

Nirupam_Bajpai@harvard.edu

\author{
Ananthi Ramiah \\ Center for International Development (CID) \\ Harvard University \\ Ananthi_Ramiah@harvard.edu
}

This paper was prepared for the Asian Economic Panel meeting held in Seoul on October 25-26, 2001 and presented to the Prime Minister of India on December 25, 2001 in New Delhi. 
India accounts for a meager 2.4 percent of the world surface area yet it sustains a whooping 16.7 percent of the world population, a little over 1 billion people residing in 29 states and 6 union territories. The variation across these states and territories is enormous in regard to physical geography, culture, and economic conditions. Some states have achieved rapid economic growth in recent years, while others have languished. The goal of this paper is to try to make some sense of the differential economic performance of India's states, especially under the forces of globalization in the 1990s. The paper may most profitably be read as a companion to the paper by Demurger, Woo, et. al. (2001), on regional differences in China's economic performance.

To address the question of regional performance, we narrow our focus to the 14 most populous states, which excludes the Himalayan states, the Northeastern states, and the 6 union territories. The included states have a combined population of 897 million, accounting for approximately $90 \%$ of India's population, and 2.7 million sq kms, accounting for $83 \%$ of India's total land area. These states are listed in Table 1, and shown in Figure 1. The variation in economic performance is large. The per capita state product varies from the poorest state, Bihar, at 1010 rupees per month and population of 82 million, to the richest, Maharashtra, at 4853 rupees per month and population of 96 million. Growth performance has been equally varied, with the slowest growth in state per capita income in Bihar, at -0.2 percent per year during 1992-98, compared with the fastest growth in Gujarat, at 7.8 percent per year (Table 4).

The differential performance across states has begun to raise important policy questions within India. To what extent are the differences a manifestation of global economic forces acting upon India, especially during a period of economic liberalization, and to what extent do they reflect differences in economic policies at the state and union level? Will market reforms tend to make the rich states richer in relative terms, with the poor states lagging ever farther behind, or will market reforms lead to economic convergence across states? Specifically, are the poorest states (especially the so-called BIMARU states of Bihar, Madhya Pradesh, Rajasthan and Uttar Pradesh) condemned to fall further behind the front runners, at least in relative terms?

In the case of China, Demurger et. al. found that the underlying drivers of economic growth, and hence the tendencies towards convergence or divergence, differed markedly across sub-periods, especially as a result of major shifts in the economic policy regime. During the first phase of China's market reforms, for example, during 1978-84, the dismantling of the communes and the partial liberalization of food production gave a great boost to major food producing regions. By the late 1980s, however, international trade had become the major driver of economic growth, and as a result the coastal regions spurted ahead of the interior provinces, a pattern which obtains till now. 
In India, we must similarly distinguish between policy regimes, especially the era of state planning up to 1991 and the market-reform period since 1991. In the planning period, international trade played only a minor role and industrialization was affected heavily by state investment plans, which attempted -- at least mildly -- to promote the laggard regions. One great impetus to national growth came via the Green Revolution, which led to sharp increases in grain productivity in regions such as Punjab and Haryana specifically adapted for the improved crops, mainly wheat. After 1991, market forces and international trade have played a larger role, though the insertion of India into the global economy has been much less dramatic than in the case of China. Still, we would expect that coastal regions to be advantaged relative to interior regions after 1991, as the coastal regions face much lower transactions costs in participating in global trade and investment.

Several studies of high-income market economies undertaken during the 1990s, for the U.S., Japan, and regions within Western Europe, found evidence for strong convergence among regions (see Barro and Sala-I-Martin, 1995, Chapter 11). We find little evidence of comparable convergence among Indian states, similar to the findings for China. This raises an important question as to why some countries or regions demonstrate inter-regional convergence while others, like China and India, do not. In China and India, it appears that geographical variation across regions may block or slow the convergence of incomes.

The paper is organized as follows. Section II analyzes the results of convergence among Indian states during the period 1980-98. In Section III we analyze the economic performance of the states under study. In Section IV, we attempt to unravel some mysteries at the state level. Policy implications and directions for future research are discussed in section V.

\section{Convergence among Indian States - 1980-98}

\section{Previous Studies on Convergence across Indian States}

A number of studies covering different time periods have examined whether per capita income levels have been converging or diverging in India. Most of the papers, like ours, find a tendency towards divergence rather than convergence.

Nair 1 (1971) analyzed the inter-state differences between 1950-60 and found that there was no noticeable reduction in the income differentials. In other words, the first decade of Indian planning does not seem to have witnessed any tendency towards convergence of income levels. Similarly, Chaudhury (1974) in a paper studying state income inequalities between 1950-70 concluded that the degree of state income

\footnotetext{
${ }^{1}$ Analyzing the nature of change in inter-state income differentials, the author concludes that neither the changes in the degree of industrialization nor the labor productivity helped reduce income disparities.
} 
inequality had remained unchanged. Majumdar and Kapoor (1980) suggest that over the period 1962-76, there has been a steady increase in the inter-state inequalities of income in India.

Gupta (1973) studying the role of the public sector in reducing the regional income disparity in the Five Year Plans suggests that the public sector investment activities over the period 1950-66 have contributed to reducing the spatial income disparity in the country. The public sector net investment constituted nearly 70 per cent of the total net investment over the Fourth plan period. Hence, the public sector influence in reducing regional income disparities was notable. Similarly, Sarkar ${ }_{1994)}$ studying the pre-reform period finds a strong link between regional imbalances and Plan outlays. He finds that per capita Plan outlays were strongly linked with per capita consumption of electricity, per capita expenditure on health, percentage of villages' electrified and effective literacy rates.

Dholakia (1994) analyzing 20 Indian states over the period 1960-90 finds marked tendencies of convergence of long-term State Domestic Product (SDP) growth rates ${ }^{\square}$. This appears to be due to the

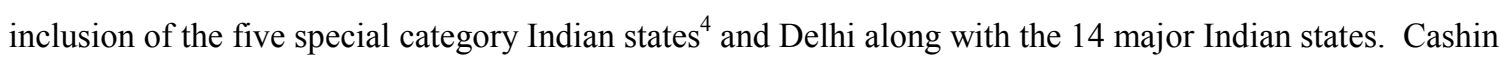
and Sahay (1996) also reach similar conclusions as Dholakia, finding absolute convergence in a study of 20 states over the period 1961-91.

Rao, Shand, and Kalirajan (1999), by contrast, suggest that per capita SDP in the Indian states have tended to diverge rather than converge. Per capita SDP growth is positively related to their initial levels. States with better infrastructure and human resources have had an edge over the others in attracting investment in the post-reform era. Dasgupta et. al. (2000) also report a distinct tendency for the Indian states to have diverged during the period $1960-95$ as far as per capita SDP is concerned. ${ }_{\text {Kurian (2000) }}$ finds widening regional disparities among the Indian states and a clear dichotomy between what he calls the forward and backward states. The former having higher levels of per capita income, better infrastructure, higher per capita resource flows and private investment and better social and demographic indicators.

Ahluwalia (2001) analyzing the economic performance of the Indian states during the post-reform period suggests that not all the richest states got richer relative to poorer states. He cites Punjab and Haryana as two key examples. While these were the two richest states in 1990-91, their growth rates of per

\footnotetext{
${ }^{2}$ Studying 15 major states of India, the author employs principal component analysis to construct a composite index of development according to which Punjab scores the highest and Bihar the lowest.

${ }^{3}$ Interestingly, he identifies 1980 as the year from when several of the lagging states started growing and the leading states beginning to stagnate.

${ }^{4}$ These are the states of Assam, Himachal Pradesh, Jammu \& Kashmir, Manipur and Tripura. Classified as special category by the Planning Commission with large hilly terrain.

${ }^{5}$ In terms of the shares of the different sectors within each state's SDP, they find a tendency for increasing similarity across states in sectoral composition.
} 
capita SDP in the 1990s were not only lower than in the 1980s, but also in both cases actually fell below the national average. He also points out that not all the poorer states lagged behind. While suggesting that two poor states, Rajasthan and Madhya Pradesh had performed well, Alhuwalia does not offer an explanation for their better performance, however.

The conclusions of these studies differ according to which group of states is examined. When focusing on the most populous states, there seems to be little evidence of convergence, while there may be some convergence of the small Northeastern states with the rest of the country. Our findings, which also focus on the 14 most populous states and leave aside the question of the Northeast, similarly find evidence of overall divergence rather than convergence.

Measures of convergence

We begin with the two standard ways of examining the presence or absence of unconditional convergence (see Barro and Sala-I-Martin, p. 383-7). The first measure is the so-called $\sigma$-convergence. We measure the standard deviation across regions of the logarithm of Real Gross State Domestic Product (GSDP) per capita. There is $\sigma$-convergence if the standard deviation across states tends to decline over time. The second measure is $\beta$-convergence. Here we regress the proportionate growth in per capita SDP on the logarithm of initial income. There is $\beta$-convergence if the coefficient on initial income, denoted $\beta$, is negative and statistically significant.

In addition to looking at $\sigma$-convergence and $\beta$-convergence across the 14 states, we also divide the states into two groups based on GSDP per capita, and examine convergence within these two subgroups. Group I includes the high-income states of Maharashtra, Punjab, Haryana, Gujarat, Tamil Nadu, West Bengal, Karnataka and Kerala. Group II includes the poor states of Rajasthan, Andhra Pradesh, Madhya Pradesh, Uttar Pradesh, Orissa, and Bihar. Table 2 shows that the states in Group I circulated in ranking within the top 8 positions in all the years in question.

\section{$\underline{\sigma-C o n v e r g e n c e ~ M e a s u r e ~}$}

\footnotetext{
${ }^{6}$ We have only used states with population above 10 million. Delhi is not included (despite having a huge population) because it suffers/benefits from the implications associated with being the capital city. Assam is not included because of incomplete data.

${ }^{7}$ All the data in this paper (unless otherwise indicated) is calculated from National Accounts Statistics of India 1950-51 to 1996-97; Mumbai, October 1998; EPW Research Foundation. 1997-98 and 1998-99 GSDP per capita levels are calculated from WP No.96 'State Level Performance Under Economic Reforms in India' by M.S. Ahluwalia, Center for Research on Economic Development and Policy Reform, Stanford University.
} 
Figure 2 plots standard deviation across the states of the log real GSDP per capita. We can see that all the 14 states (when pooled together) show an increasing standard deviation between 1980-1990 and an increased rise in that standard deviation in the post-reform period. There was an overall rise in inequality (between 1980 and 1998) of 2.40 percent per annum. Of the two periods within that time frame, it is the 1992-98 period that caused the most divergence 2.14 percent per annum compared to 1.24 percent per annum in 1980-1990. Thus there was no $\sigma$-convergence during either of the periods under question.

It is interesting to see that the Group II states exhibit much greater volatility in dispersion than the Group I states, in addition to exhibiting the greater absolute dispersion (even though Group II states started off with considerably lower standard deviation than their counterparts). This is the case for the both the periods under question. From 1980-90, Group I states see an increase in dispersion of a mere 1.24 percent per annum compared to 2.51 percent per annum within the Group II states. During 1992-98, Group I states see a decrease in dispersion of 0.35 percent per annum while Group II states witness an increase of 4.61 percent per annum. Thus, it appears that the richer states experienced a degree of convergence during the post-reform period, while the poorer states did not.

\section{ß-Convergence Measure}

The lack of $\sigma$-convergence is mirrored by a lack of $\beta$-convergence. Thus, there is a positive coefficient on initial income in Table 3, where we regress the growth during each sub period on the log of initial income. This is done for 1980-90, 1991-98, and for the whole period 1980-98.

During 1980-90 growth patterns were divergent. As just one example, the state with the highest GSDP per capita level in 1980 was Punjab at Rs. 3020 per month and the state with the lowest GSDP per capita level was Bihar at 1062 per month. In terms of growth rates from 1980/81 to 1990/91, Punjab grew at 3.78 percent per annum and Bihar at 2.94 percent per annum. As Table 4 shows, this made Punjab the $6^{\text {th }}$ fastest growing state and Bihar the $10^{\text {th }}$. More generally, the richest states also had the highest growth rates, as shown in the table. The only notable exception is Rajasthan, which had the second lowest initial GSDP per capita level, but was the fastest growing state during the 1980s. Apart from Rajasthan, all states have generally grown in a manner that perpetuates divergent trends during the pre-reform period.

Do states exhibit convergent trends during the post-reform period? The fastest growing state is Maharashtra, but it also has one of the highest GSDP levels of the 14 states. Overall there is a significant positive relationship between initial income in 1990 and growth during the 1990s, indicating divergence. The regression evidence suggests that $\beta$-divergence was especially marked for Group I states in the postreform period. 
In Table 5 we decompose the inter-state variance of income as equal to the variance within Groups I and II and the variance between the two groups. ${ }^{\square}$ The method used for calculating variance decomposition is detailed in the appendix. During 1980 to 1990, variance increased within Groups I and II, as well as between the two groups. From 1992 to 1998 (1991 is left out because it represents a structural break in the data due to the crisis), there is a smaller increase in dispersion in overall variance of 20.2 percent as compared with 35.5 percent in the earlier period. Over the whole period ${ }_{2}$ there is an increase in dispersion within Group I of a mere 0.8 percent per annum, while the dispersion within Group II increased by 17.17 percent per annum. There was also an increase in the dispersion of average incomes between the two groups of 3.83 percent per annum. Thus, we can conclude that the increase in overall dispersion during the second period was driven by increased dispersion within the Group II states.

\section{Conclusions on inter-state convergence}

By both standards of convergence, India demonstrated overall divergence during the period 1980 98, as well as during both the pre-reform and post-reform sub-periods. Divergence was most notable within the poorer group of states. This finding is consistent with the experience of China in the post-reform period, but differs from the findings for the U.S., Japan, and European regions.

\section{Economic Performance of the States}

We hypothesize that regional differences in growth reflect regional differences in the marginal productivity of investments by sub-sector. To some extent, the relative returns to investment in each subsector depend on the general business environment, but to an important extent, they also depend on specific geographical factors. Some of these geographical considerations are described in Table 6.

Agriculture can occasionally be a leading sector in economic growth, either on the basis of a spurt in agricultural productivity or on the basis of cash-crop exports ("vent for surplus"). In the case of India, agricultural-productivity-led growth occurred in one major historical period, the Green Revolution, dating from 1965-66 to the early 1980s. The Green Revolution was centered on short-stemmed, high-yield wheat, and to a lesser extent paddy rice, with both crops depending on irrigation and intensive application of fertilizer. ${ }^{0}$ The epicenter of the Green Revolution was Punjab and Haryana, and to a lesser extent other states of the North Indian Plains (as far east as Bihar) and southward to Rajasthan, Gujarat, and

\footnotetext{
${ }^{8}$ The variance decomposition is calculated as follows: Overall Variance $=\mathrm{a}^{*}$ Within Group I Variance + b*Within Group II Variance $+c^{*}$ Average between Group I and Group II Variance. The constants $a, b$ and $c$ are weights that depend on the number of states in each group (see technical appendix for a more detailed explanation).

${ }^{9}$ Most rice farmers were too poor to introduce the high-yield varieties of rice, which required substantial applications of fertilizer, as well as irrigation. Also, the taste of the rice was unfamiliar, and public acceptance was limited. Therefore, rice became the "orphan" of the Green Revolution [Tirtha, p. 268].
} 
Maharashtra. High-yielding rice varieties made their impact most powerfully in West Bengal and Tamil Nadu. Note that China, like India, experienced one short-lived burst of agriculture-led growth, with the dismantling of the communes and consequent jump in food output during 1978-84.

Almost all the regions among the Group II states (except perhaps much of western Rajasthan and parts of Western Madhya Pradesh and southern Uttar Pradesh) have the agro-climatic potential to yield high returns in agriculture because of reasonable to high rainfall and availability of perennial river waters. Much of the reason for poverty in these states is thus a human failure rather than it being a result of natural factors. While it may be useful to identify states with high/low incidences of poverty, there are states, which have high variations within them both owing to historical/economic antecedents and agro-climatic factors. This is typically true of the larger states though such variation exists in smaller states as well.

A more disaggregated, NSS region-wise picture of poverty (head count ratio) shows that, to a significant extent, there are heterogeneities in each state except perhaps Bihar, which is uniformly poor. Sharp contrasts are witnessed in Andhra Pradesh, Karnataka and Maharashtra, though variations can be seen in smaller states like Haryana, and Punjab as well. The regions have been segregated by low (up to 20 percent), medium (21-40 percent), high (41- 60 percent) and very high (more than 60 percent) levels of poverty. Southern Bihar, southern Orissa, southwestern Madhya Pradesh and southern Uttar Pradesh fall in the very high poverty bracket. These regions are composed of the districts in Chotanagpur and Santhal Parganas in Bihar, Koraput and Phulbhani districts in Orissa, the Jhansi region in Uttar Pradesh and its adjacent regions in Madhya Pradesh, including Betul, Khandwa and Hoshangabad. Two peculiar features of these regions are, that either they are mainly tribal (except Jhansi) or rocky and dry, yet densely populated because of their agro-climatic features. The one major inference drawn here is that tribal areas are predominantly and distinctly poor.

The high priority (41-60 percent) areas are in Bihar, portions of Madhya Pradesh, inland Maharashtra, northern Tamil Nadu, eastern and central Uttar Pradesh, and parts of West Bengal. The reasons here are similar; that tribal, thickly populated semi-arid areas, and those, which have been neglected historically, are poor. Parts of West Bengal have made strides in poverty alleviation. Medium level poverty persists in regions of western states; a few regions have made more progress than others, compared to the eastern ones where there is uniform poverty. Typical examples are, Madhya Pradesh, Maharashtra, Tamil Nadu and Uttar Pradesh. Lastly, the western coastal regions, entire Andhra Pradesh, Punjab, parts of Madhya Pradesh and Rajasthan, which are a continuum of a north-south belt having experienced green revolution, are pockets of low poverty.

The manufacturing sector is a much more consistent engine of growth, and it is likely to play a growing role after 1991 with the opening of the economy. As China's experience demonstrates, trade liberalization in a low-wage, surplus-labor environment permits a rapid expansion of export-oriented 
industry, which can absorb large numbers of workers to provide goods for the world market. India's insertion into the world economy has been much less dramatic, and successful, than China's, but it has been real nonetheless. The share of exports of goods and services in GNP was stable at 7 percent in 1980 and 1990, and after reforms rose to 11 percent in 1999 (WDR, 1997 and 2000/1, Table 13). In China the comparable share rose from 6 percent in 1980 to 18 percent in 1990 and 22 percent in 1999. There are many differences in this experience between China and India. China's reforms were bolder in promoting both FDI and manufacturing exports (Bajpai and Sachs, 2000), and China benefited from the vast inflows of FDI from overseas Chinese investors, especially in Hong Kong, Taiwan,China, and Southeast Asia.

The most likely site for sustained manufacturing growth in India, like China, is along the coast, especially at the four large port cities of Mumbai (Maharashtra), Kolkata (West Bengal), Chennai (Tamil Nadu), and Kandla (Gujarat). Coastal, urban-based industry can serve both the internal market and the international market, and can more readily make logistical links with foreign suppliers and customers than can interior-based enterprises. New export-oriented units are therefore heavily concentrated on the coast (Table 7). Manufacturers in interior regions can of course service the domestic market, particularly in consumer goods such as processed foods, but the potential for rapid growth based on the internal market tends to be more limited than the growth based on exports to the world market. For this reason we have seen much faster growth in coastal China than in the interior of China.

The tourist sector can also be a source of export-led growth, but in a country the size of India, it is likely to play a secondary role except in some local niches. Tourist potential is, of course, very much geographically determined, as it depends on the physical environment (e.g. beachfront), the presence of historical sites, and easy access to transport nodes, especially international airports. Rajasthan has been the major state with the most significant growth and scale of the tourist industry, based on the popularity of tourist visits to Jaipur and Udaipur and the proximity to Delhi.

High-tech services, such as information-and-communications-based industry (e.g. software production), or financial services, are almost always reliant on a network of universities and an urban labor market. These sectors are much less dependent on coastal access, however, since much of their business can be transacted over telephone and Internet connections. A high quality of life of the location, as an attraction for highly mobile skilled workers, probably looms larger in these sectors than in other sectors of the economy. The most important state for service-sector activities is surely Maharashtra, as it combines the country's financial center with an important IT-based industry. Other key states include Tamil Nadu, Karnataka, Delhi, and to a lesser extent Andhra Pradesh. (Table 8).

Foreign investors have multiple motivations: to service the domestic market; to exploit sitespecific natural resources (e.g. mining); and in low-wage countries to establish export platforms in labor- 
intensive goods, or labor-intensive stages of the production process, or in standardized technologies that are easily transferable to lower-wage settings. In general, coastal access is a huge benefit for all exportplatform manufacturing, as we've seen clearly in the case of China. More generally, FDI is attracted to urban areas and to natural resource deposits. Interior cities (such as Bangalore and Hyderabad) may be attractive for IT-based activities, which do not depend on coastal access. While the data on state-by-state FDI are spotty, we present in Table 9 the cumulative FDI approvals by state, on an aggregate and per capita basis, for the years 1991 - 01. A simple regression confirms that FDI flowed mainly to the urbanized states and to the states with large mining sectors as a percent of GNP (especially Orissa and to a lesser extent Madhya Pradesh). 10

FDI per capita $=-4682+220(\%$ Urban $)+459(\%$ Mining in GSDP $)$

$\mathrm{N}=14$

$\mathrm{R}^{2}=0.62$

Taken in total, these considerations suggest that urbanization is likely to be a key determinant of economic growth in the 1980s and 1990s, as we would expect that already existent urban areas would be the preferred location for new investments in manufactures and services. As we see in Table 10, the extent of urbanization varies widely, between a low of 13 percent in Bihar and Orissa and 38 percent in Maharashtra as of 1991, with the relative proportions of urbanization by state relatively constant over the past 30 years. The degree of urbanization itself depends on underlying geographical factors, especially the location of the main national ports (with their origins in history and the geography of natural harbors), as well as the productivity of agriculture in the region. Regions of high agricultural productivity tend to support a larger proportion of the local population in an urban setting, while regions of low agricultural productivity tend to have a high proportion of the population in peasant, subsistence agriculture.

Empirically, we find, for example, that two factors - having a major port (Maharashtra, Tamil Nadu, West Bengal, and Gujarat) and having a dry steppe climate (Bs) suitable for wheat production - accounts for two-thirds of the variation in urbanization rates across the fourteen states: $\square$

Urbanization $(\%)$ in $1991=19.4+11.1$ Major Port $+12.6 \%($ Pop in BS Climate $)$

$\mathrm{N}=14$

$\mathrm{R}^{2}=0.68$

As we would expect, the rate of growth of GSDP per capita is highly correlated with the extent of urbanization at the beginning of the period. The regression results are shown in Table 11. In a regression of growth during 1980 to 1998 on initial income in 1980 and urbanization as of 1981, the urbanization

${ }^{10}$ The dependent variable is cumulative approvals of FDI in rupees per capita. 
coefficient is highly significant with a coefficient 0.13 and t-statistic 5.3 (regression 1). A remarkable 82 percent of the cross-state variation in growth is explained by just this variable, and with no hint of any conditional convergence after controlling for the degree of urbanization. The regression estimate shows that a 10-percentage-point higher rate of urbanization is associated with 1.3 percentage points per year higher annual growth. A simple bivariate regression without initial income shows the same results (regression 2). The relationship between 1981 urbanization and growth during 1980-98 is shown in Figure 3.

During 1980 - 90 the Green Revolution continued to play a role in growth differentials across states. To capture the effect of the Green Revolution, we construct a dummy variable equal to 1.0 in Punjab and Haryana (the epicenter of high-yield wheat), 0.25 in Gujarat, Maharashtra, and Rajasthan, and 0 elsewhere. This variable has a coefficient of $3.54(t=4.01)$ in the growth regression for the period 198090, holding constant the initial income, the degree of urbanization in 1981. Rajasthan is an outlier in this regression, with growth more than 1 percentage point per year faster than is otherwise explained (regression 3). This may be due to the boom in tourism, or to the rapid electrification of the state in the 1980 s, or to a more significant effect of the Green Revolution than is captured by the value 0.25 , or to some other unmeasured effect. Interestingly, holding constant urbanization, the Green Revolution variable, and the Rajasthan variable, there is evidence of conditional convergence, with the slower states achieving faster growth than the richer states. This is the only regression result in which we find this conditional convergence.

By the 1990s, however, the Green Revolution effect has disappeared entirely, as has the conditional convergence and the fast growth of Rajasthan (regression 4). ${ }^{.2}$ The only variable that accounts for cross-state growth in the 1990s is urbanization as of 1991 (regression 5), with a point estimate of the urbanization coefficient that is somewhat higher than in the $1980 \mathrm{~s}$ ( 0.30 compared with 0.13 ). A simple bivariate regression of growth during 1991-98 on urbanization in 1991 is also shown (regression 6), with this single variable accounting for 71 percent of the variation. It is plausible that economic liberalization has given an added boost to the growth-promoting benefits of urbanization, especially for the coastal cities and the main cities engaged in IT exports (Bangalore, Chennai, Hyderabad, and Delhi).

Consistent with our view of urban-led growth (and export-led) growth during the past decade, we find that the gap between urban and rural expenditure per capita has widened in the past decade. In Table 12, we show the urban-rural expenditure ratio for 1987-88 and again for 1999-2000 by state, with the growth in the ratio between the two dates in the final column. Simple regression analysis (not shown)

\footnotetext{
${ }^{11}$ The variable Major Port takes the value of 1 for the states Maharashtra, West Bengal, Tamil Nadu, and Gujarat, and 0 otherwise. The variable Bs is the proportion of the population (0 to 100\%) lying in the Bs (steppe) climate zone of the Koeppen-Geiger climate classification.

${ }^{12}$ The coefficient on a dummy variable for Rajasthan is still positive but is no longer statistically significant.
} 
confirms that the urban-rural ratio in 1999-2000 is higher in more urbanized states, and lower in the states that benefited most from the Green Revolution (Punjab and Haryana). Importantly, the increase in the ratio is highest in the urbanized states as well, with Bihar being something of an outlier (as Bihar shows a large increase in the urban-rural ratio, yet has a relatively low level of urbanization). This result has also recently been reported by Radhakrishna (2002), who writes that "The benefits of better income growth during the 1990s seem to have benefited the urban areas more than the rural, thus aggravating the urban-rural divide" (p.248). He quotes Sheila Bhalla (2000) as finding that "employment growth during the 1990s was concentrated in urban areas."

There are major differences across states in the area of policy reform. A few of the Indian States have been more reform-oriented, such as Maharashtra, Tamil Nadu, Gujarat, Karnataka and Andhra Pradesh, but states, such as Haryana, Kerala, Orissa, Madhya Pradesh, Punjab, Rajasthan and West Bengal have wide ranging unfinished reform agendas to deal with. Of course, Bihar and Uttar Pradesh are even further behind. Data on real annual average growth rates of per capita gross state domestic product bear testimony to the fact that four out of the five states that are more reform-oriented (with the exception of Andhra Pradesh) are also the fastest growing states in India in the post-reform period (Bajpai and Sachs, 1999). Interestingly enough, amongst the Southern states, both in Karnataka and Tamil Nadu, per capita incomes began to surge and exceed the national average since 1991-92. On the other hand, amongst the relatively poor reformers, Bihar, Madhya Pradesh, and Uttar Pradesh, and to a certain extent Orissa, have lagged far behind the all-India average, as also in the growth of SDP per capita of other states.

With the initiation of economic reforms in 1991, the role of private investment has acquired a great deal of significance. States are now in competition with one another to attract private investment, both domestic and foreign. Within states, the flow of investment has tended to be skewed in favor of the urban areas. State-level data on FDI approvals (aggregate FDI approvals between 1991-01) as shown in Table 9 suggest once again that the relatively fast moving reformers have tended to attract higher levels of foreign direct investment. Gujarat, with a population of 50 million, received over a fifth of private investment proposals, whereas Bihar with a population of 83 million barely managed a share of 5 percent of such proposals. Maharashtra and Gujarat account for 37 percent of total investment proposals, while Bihar, Madhya Pradesh, Orissa, Rajasthan and Uttar Pradesh, taken together, were able to attract only 26 percent of investment proposals.

One key variable, which we have not been able to analyze in detail, is public-sector investment, especially investment funds from the central government allocated to the state governments in India's fiveyear investment plans. The data we collected to date have been too spotty for a serious analysis of the role of public investment spending in cross-state growth. There are certainly hints that such investments have made a difference, at least in some places and times. The rapid electrification of Rajasthan's villages 
between the 1980s and 1990s probably helps to account for the otherwise unexplained growth of that state (Table 13). This is an area to which we will return in a later study.

\section{Accounting for the lack of convergence}

It is surprising, but robustly the case, that after controlling for urbanization alone there is no evidence whatsoever of conditional convergence. We did not find any candidate explanatory variables that once controlled for left signs of conditional convergence. This poses a major issue of interpretation. Why is it that the U.S. states displayed unconditional convergence in most decades of U.S. history, and similarly for Japanese prefectures and European regions, but India and China do not show signs of conditional convergence much less unconditional convergence? There are several possible hypotheses for the lack of unconditional convergence:

(1) the geographical differences are larger in India and China than in the United States, Europe, and Japan (2) population movements in the United States, Europe, or Japan more readily arbitrage differences across regions

(3) policies of the national or regional governments prevented convergence

(4) economic convergence is easier at higher levels of economic development than in China and India

We find some merit in each of these possibilities. Certainly the intrinsic economic advantages or disadvantages of Japanese prefectures and West European regions are much smaller than in the case of either India or China. Consider coastal access, for example (Table 14). In Japan, 97 percent of the population lives within 100km of the coast, and in Europe, more than half the population of every country in the European Union lives within $100 \mathrm{~km}$ of the coast or an ocean-navigable waterway (like the Rhine or the Danube). 13 On average, 51 percent of the population lives within $100 \mathrm{~km}$ of the coast, and 89 percent lives within $100 \mathrm{~km}$ of the coast or a navigable waterway. The U.S., it would seem is much more like China and India, with a large proportion of the land area far from the sea or ocean navigability. Yet a surprisingly high proportion of the U.S. population lives within $100 \mathrm{~km}$ of the coast or ocean-navigable waterway: an estimated 65 percent.

Of course one of the reasons that the U.S. has such a high proportion of the population at the coasts and along navigable waterways is that it has highly efficient agriculture, which can feed the entire population (and much more) with just 2 percent of the labor force. For this reason, few people in the United States are "bound to the land" in the economic sense of needing to be in the place where food is grown. With much lower food productivity in China and India (itself a reflection in part of the long history

\footnotetext{
${ }^{13}$ By ocean-navigable river we mean that ocean-going vessels may proceed up and down the river to the ocean.
} 
of much higher man-land ratios in Asia), a much larger part of the population is needed to produce food. This in turn means that populations are "stuck" in the interior of the country, much less able to participate in international trade and globalized production systems (e.g. outsourcing for multinational firms). Large numbers of poor near- subsistence farmers therefore live in the hinterland of China and India, regions that are not part of convergent growth except to the extent that households migrate in large numbers.

Note that climatic variability is also much lower in Europe, the U.S., and Japan than it is in India and China. India has substantial proportions of population in tropical, arid, sub-tropical, and highland ecozones, whereas the overwhelming proportion of U.S., European, and Japanese populations are in temperate ecozones. China has large variations as well, though China has only a small proportion of the population in tropical ecozones, which have proved most difficult for development in other parts of the world (including India). These differences are shown in Table 15. Just as with the variation in access to the sea, the climatic variation mostly likely puts a brake on cross-regional convergence.

This brings us to the question of migration. In China, migration is limited by the household registration system, which has blocked the legal migration of families from the hinterland to urban areas. In India migration is not restricted, yet poor families without social safety nets apparently face such high costs and risks of migration that internal labor flows are not powerful enough to create forces of convergence. Exactly why this is the case is beyond the scope of this paper, but is certainly worthy of much closer investigation. We know too that in the case of China, the policy regime in the 1980s and 1990s favored the already-favored coastal provinces, and this accounted for part of the continuing divergence between coast and interior. In India, no such preferential policies are readily discernible.

\section{Social and Demographic Factors in Convergence and Divergence}

We also examined whether social and demographic factors could account for cross-state growth

patterns. The results were surprisingly negative. The states vary considerable in social indicators, such as infant mortality rates and adult literacy (Table 16 and 17). Generally, the Southern States have outperformed the Northern states by a wide margin, and Kerala has outperformed all of the rest of the country, including its Southern neighbors. Yet, this superior performance, while undoubtedly raising the standard of well being, has not translated during this period into discernibly higher rates of economic growth at the state level. The simple correlation of growth with literacy, for example, is positive, but disappears once we control for urbanization, which is correlated both with growth and with the degree of literacy.

Kerala has reaped its returns to improved human capital (literacy and health) through increased migration, and a large flow of remittance income back to the state. This remittance income is counted as 
part of the state's income but not its Gross State Domestic Product, which is our measure of economic development used in the paper. Thus, Keralites have a higher income standard that is measured by production within the state. We speculate on why this is so in the next section.

\section{Unraveling some mysteries at the state level}

This section explores some of the mysteries of state level performance. We consider four such mysteries: (1) the mediocre growth of Kerala despite excellent social indicators; (2) the relatively fast growth of landlock, arid Rajasthan; (3) the improved growth performance of landlocked Madhya Pradesh; and (4) the poor growth performance of coastal Orissa.

\section{Kerala}

Kerala is a forerunner in human development terms. However, in the period under question, Kerala has moved from $6^{\text {th }}$ to $8^{\text {th }}$ place in per capita GSDP rankings and grew at 2.5 percent between 1980 1990 and 5.2 percent between 1992-1998. Though its growth performance has improved, making it one of the biggest beneficiaries of the reform period (moving from $12^{\text {th }}$ to $6^{\text {th }}$ fastest growing state), the question remains as to why Kerala is not among of the top states in growth performance given its outstanding results in health and education. We attribute this poor economic performance to three major factors.

Firstly, Kerala traditionally has had a very low manufacturing base. In 1981, manufacturing as a percentage of GSDP was 13.9 percent and that had risen to a meager 15.5 percent by 1991. Subrahmanian (1990) argues that Kerala's poor economic performance can be attributed to a limited focus on and growth of the commodity production sector. Although the economic structure has changed somewhat (i.e. a decline in the primary sector and a rise in the tertiary sector), it has not seen a deepening of its industrial base. The secondary sector areas that have seen growth are construction, power etc. rather than actual manufacturing activity.

Why is it the case that resource-based industries do not provide the growth potential of manufacturing (capital goods or demand based) industries? The difference between these industries lies in the fact that the latter confers inter-sectoral linkages and technical progress while the former has a tendency to stagnate. We realize that a lopsided industrial structure is a symptom rather than the cause of the problem. The causes are an insufficiency of investment, both private and public largely due to the failure of the government to implement policies effective in encouraging private investment. ${ }^{\text {Kerala's private }}$

${ }^{14}$ There are also historical reasons for the development of industry, the examination of which runs beyond the scope of this exercise. 
investment is very low - as a percentage of GSDP, investment in private projects in Kerala accounted for a mere 1.77 percent, making it the poorest state in this regard.

Kerala also receives very little of FDI as Table 9 demonstrates. However it is one of the biggest recipient states of remittances from Keralite workers abroad (mainly in the Gulf countries). The Rs 6,000

cror ${ }^{15}$ the state receives in remittances every year is about a fifth of its domestic product. These remittances are three times more than what the state receives from the Center as budget support. Between 1980 and 1995, more than Rs 31,350 crore flowed into the state from the Gulf. 6 . This disproportionately large income is due to the fact that Kerala accounts for approximately 50 percent of Indian migration abroad even though it represents only 3.4 percent of the total population of the country. Since remittance income is counted as part of the state's income but not its Gross State Domestic Product, Kerala may not be as poor a state as its GSDP figures suggest.

The lack of FDI and private investment is likely the consequence not only of the lack of an industrial tradition, but because of the relatively hostile attitudes of_state governments over the years to private investment, and as a result of a highly militant labor force which has also_resisted private investment. The labor relations problems in Kerala are notorious, with frequent work actions and opposition to privatization. The Communist Party, which governed the state for many years until 2001, had part of its base in the unions, and did not resist the labor militancy. This reputation for aggressive labor tactics has dissuaded private investors, both domestic and foreign over the years. With a change in government to Congress rule, there may also be a change in the investment climate in the state.

\section{Rajasthan}

Table 4 had demonstrated how Rajasthan recorded the overall highest growth in the pre-reform period. It grew the most in agriculture, tourism, construction and other services (among all 14 states) and was amongst the top three Group II states in manufacturing growth. What spurred Rajasthan's incredible growth spurt in the 1980s? One part of the answer is that Rajasthan received the highest per capita transfers and grants from the union government among the four BIMARU states, and was one of the top recipients of federal transfers of all states. This explanation is hardly sufficient, however, since other states such as Orissa, which received large transfers, did not experience such successful economic growth. Rajasthan's high growth remains unexplained in the literature, but should also probably be explained by four additional factors: (1) the benefits of the Green Revolution in the wheat growing areas of the state; (2) the impact on the State's agricultural output as a result of building Rajasthan's Command Canal in the early 1980s; (3)

\footnotetext{
${ }^{15}$ One Crore equals ten million

${ }^{16}$ M.G.Radhakrishnan, India Today Publication, May 12000
} 
the tremendous boost in tourism during the 1980s and 1990s; and (3) the rapid electrification of the state that took place in the 1980 s.

\section{Madhya Pradesh}

Madhya Pradesh practices direct democracy at a rate unparalleled by other Indian states. The extent to which all these reforms have aided growth in Madhya Pradesh is unclear. One would expect these experiments in direct democracy to work as long-term rather than short-term measures. However, if the reforms were both targeted and quickly and effectively implemented, there is no reason why they should not be a big determinant of Madhya Pradesh's growth in the 1990's.

Madhya Pradesh was the first state to conduct elections to panchayats in 1994. 7 By this method, it aims to give power to the people directly, rather than to their representatives. Kumar (2001) $\frac{\mathbb{L}^{8}}{\text { explains }}$ how empowering the people has enabled the government to overcome difficult situations such as water shortages. The state supplies the panchayats with some funding and technical support in order to "widen, de-silt and deepen village ponds, dig new wells and build dam checks". Thus the state government has moved to a supervisory rather than directly administrative role. Drought relief work has also particularly targeted women. For instance, the Madhya Pradesh government supports a 'food for work' program where women are given a certain amount of wheat and some limited cash in exchange for their manual labor.

\section{Orissa}

Orissa is traditionally one of India's poorest states $\left(3^{\text {rd }}\right.$ lowest GSDP in 1980). It was also the slowest growing state in the $1980 \mathrm{~s}$, at a miniscule 1 percent per annum. Its poor growth is partly attributable to its even lower agricultural growth, at 0.72 percent, though it is unclear why agricultural production has fared so poorly. Its soils and suitability for irrigation do not stand apart from more successful states. One explanation may be Orissa's vulnerability to floods and resulting devastation each year, as the result of tropical cyclones. Orissa is also notable for having the most productive mines and quarries in the country (which grew by $15.6 \%$ during 1980-90), adding further to the mystery of poor performance.

In the post-reform period, Orissa grew somewhat more rapidly than in its pre-reform phase, 2.53 percent per annum, but was still near the bottom of the states in growth performance $\left(12^{\text {th }}\right.$ during 1991-98 as opposed to the $14^{\text {th }}$ during 1980-90). In some ways, moreover, Orissa became an innovator in economic

17 Behar, Amitabh, Madhya Pradesh: Gram Swaraj -- Experiment in Direct Democracy, Economic and Political Weekly, June 3-9 2001

${ }^{18}$ Kumar, Venkatesh B., Madhya Pradesh: Panchayats and Water Scarcity, Economic and Political Weekly, July 21-27 2001 
reforms. It was the first state to reform its power sector and it has strongly set out industrial policy. Orissa is also the first state in India that has announced new agricultural and tourism policies.

In the post-liberalization period, Orissa ranks 6th in foreign investment, and at the top in per capita terms. The reason for Orissa's sudden emergence is its industrial policy, which has directed investors towards Orissa's abundant natural resources. As Kalwajit Singh (1997) observers, "Orissa has 90 percent of India's chrome ore and nickle reserves; 70 percent of bauxite; and 24 percent of coal reserves. With no other state having such abundance of natural resources, the big business houses have no option but to set up steel, alumina and coal based power projects in Orissa only."

Orissa's post-reform ability to attract both private and foreign investment makes it plausible that its pre-reform failure was due primarily to ineffective or non-existent industrial policy to exploit its mineral wealth. However, it remains a puzzle as to why its agriculture sector grew so poorly. In the post-reform period, the sector declined more, experiencing a contraction in growth of 0.5 percent. Despite its resource wealth, Orissa is still a predominantly agricultural state, and thus its poor agricultural performance augurs very badly for its future income growth and income distribution.

One possible explanation that needs further focus is the very high proportion of tribal populations in Orissa. There are 62 distinct tribal groups in the state, concentrated heavily in the Western hills. Around 25 percent of the state population is tribal, the highest in all of the country. As elsewhere in India, these tribal populations tend to have distinctively lower social indicators in health and education, and to suffer social and political exclusion. We have not examined this factor in sufficient depth, however, to reach strong conclusions about its relevance for Orissa's continued slow growth.

\section{Policy Implications and Directions for Future Research}

The main finding of this study, in conjunction with the study on China by Demurger et al., is that the forces of convergence, absolute and conditional, are very weak. We should probably expect that India's growth will continue to be urban-led, favoring those states where urbanization is already high - perhaps due to coastal access or to the relatively high productivity of agriculture. There is little to ensure that growth will equalize across regions. Still, the assessment is hardly a pessimistic one, for several reasons.

First, there is much more growth potential in India than has been achieved to date. While India's states have varied in per capita growth rates between 2 and 8 percent per annum, China's provinces have ranged between 8 and 13 percent per year during 1992-8 (Table 4, Demurger). There are many coastal

19 Singh, Kalwajit, Orissa: From "Backward" to "Investor's Paradise", August 1997, http://www.corpwatch.org/trac/feature/india/globalization/orissa.html 
cities that have not begun to attract foreign direct investment for export-led growth. The most stunning example is Thiruvananthapuram (Trivandrum), Kerala, which boasts a skilled labor force, a natural harbor, and yet almost no FDI to show for it. With a new government in that state declaring its intention to begin attracting FDI, it is quite likely that FDI-led exports will begin to grow from that state. Other coastal cities that could be much more dynamic include Cochin, also in Kerala; Bhubaneshwar, the capital city of Orissa; and Vishakhapatnam, the major port of Andhra Pradesh.

There are many reasons why these other coastal port cities have not rapidly developed, but the continuing power of the central government over regional infrastructure (airports, major highways, power, telecomms) have certainly frustrated the capacity of reform-minded state governments to move more rapidly in economic reforms. In China, the provincial governments have had ample leeway in making key infrastructure investments, while in India, the powerful monopoly state enterprises in key infrastructure sectors have resisted competition, especially from potential foreign investors. This is changing, but gradually and not without continued resistance.

India, like China, but unlike the United States, boasts several cities of population greater than 1 million that are far from the coast or navigable waterways. These include: Lucknow (Uttar Pradesh), Kanpur (Uttar Pradesh), Hyderabad (Andhra Pradesh), Bangalore (Karnataka), all 100 - $500 \mathrm{~km}$ from the sea; and Delhi, Jaipur (Rajasthan), Bhopal (Madhya Pradesh), and Nagpur (Maharashtra), all 500 - 1000 $\mathrm{km}$ from the sea. In the United States, only Dallas among cities of 1 million or more population is more than $100 \mathrm{~km}$ from the sea. ${ }^{20}$ These cities can readily support industry for the internal market, as well as ITbased services. With a high-quality internal highway system among these major cities, though, even these inland urban areas could become export oriented. Establishing improved transport and communications networks (including fiber optic cables) across the major cities is surely a high priority.

India will, however, likely continue to face the same problems as China in the inland areas, particularly the inland rural areas. Even with faster overall growth, the inland areas are likely to grow more slowly than the coastal areas, opening a widening gap between the fast and slow-growing regions. This does not mean absolute immiserization of the interior, of course, but it will likely provoke political pressures as well as increasing internal migration from rural areas to cities and from the interior to the coast. India, however, probably has an advantage over China in that China's far West is much farther from the coast than India's heavily populated interior regions of the Gangetic valley. China has 4 cities of more than 1 million that are more than 1,000 km from the coast (Chengdu, Lanzhou, Urumqi, and Xian) while India has none. All of India's large interior cities are within $1000 \mathrm{~km}$ of the coast.

\footnotetext{
${ }^{20} 11$ U.S. cities are far from the coast, but in all cases but Dallas they are close to a navigable waterway. These large interior cities are: Buffalo, Chicago, Cincinnati, Cleveland, Dallas, Detroit, Milwaukee, Minneapolis, Pittsburgh, Portland, St. Louis.
} 
Just as in China, a careful balance will have to be struck between two kinds of investments in the rural hinterland (e.g. in Uttar Pradesh and Bihar): physical infrastructure in roads, rail, airports, and telecomms to bring these regions closer to the international markets, and investments in human capital, mainly education and health, to raise the productivity of the rural population. The latter investments may end up attracting jobs to the interior, eager to benefit from an increasingly skilled labor force; or it may provoke large-scale migration to more economical coastal regions. Either way, however, the currently impoverished populations would benefit from rising living standards, wherever in India they are enjoyed. 


\section{References}

Ahluwalia, M.S., (2001). "State Level Performance Under Economic Reforms in India", Working Paper No. 96, Center for Research on Economic Development and Policy Reform, Stanford University.

Annual Survey of Industries, Ministry of Planning, Government of India, various issues.

Barro, R. and X. Sala-I-Martin (1995). Economic Growth. New York: McGraw-Hill, Inc.

Bajpai, Nirupam and Jeffrey D. Sachs, (2000). "India's Decade of Development", CID Working Paper No. 46, Center for International Development, Harvard University.

Bajpai, Nirupam and Jeffrey D. Sachs, (1999). "Progress of Policy Reform and Variations in Performance at the Sub-National Level in India", Development Discussion Paper No. 730, Harvard Institute for International Development, Harvard University.

Bajpai, Nirupam and Jeffrey D. Sachs, (1996). "Trends in Inter-State Inequalities of Income in India", Development Discussion Paper No. 528, Harvard Institute for International Development, Harvard University.

Bhalla, S. (2000). "Behind Poverty: The Qualitative Deterioration of Employment Prospects for Rural Indians," Working Paper Number 7, Institute for Human Development, New Delhi.

Bhargava, S. and Joshi, V. (1990) "Increase in India's Growth Rate, Facts and a Tentative Explanation", Economic and Political Weekly December 1-8.

Cashin, P and R Sahay (1996). "Internal Migration, Center-State Grants, and Economic Growth in the States of India", IMF Staff Papers, Vol. 43, No. 1.

Census of India, 1991 and 2001 "Provisional Population Totals".

CMIE (2000) “Agriculture”, November.

CMIE (1997) "Profile of States", March.

Chaudhury, Mahindar D (1974). "Behaviour of Spatial Income Inequality in a developing Economy: India 1950-76 " Paper presented at the Ninth Conference of the Indian Association for Research in National Income and Wealth.

Chen, Jian, and Fleisher, Belton M. (1996) "Regional Income Inequality and Economic Growth in China." Journal of Comparative Economics, 22 (2), April

Das, S.K. and Barua, A. (1996). "Regional Inequalities, Economic Growth and Liberalisation: A Study of the Indian Economy", The Journal of Development Studies, Vol.32, No.3, Feb. pp.364-390.

Dasgupta, D, Pradip Maiti, Robin Mukherjee, Subrata Sarkar, and Subhendu Chakrabarti (2000). "Growth and Interstate Disparities in India", Economic and Political Weekly, Vol. XXXV, No. 27, July 1.

Demurger, S., Sachs, J., Wing, T.W., Bao, S., Chang, G., and Mellinger, A. (2001) “Geography, Economic Policy and Regional Development in China", presented at the April AEP Conference, Harvard University, Cambridge, Massachusetts, forthcoming Asian Economic Papers, Vol. 1, No. 1.

Démurger, Sylvie, (2001) "Infrastructure Development and Economic Growth: An Explanation for Regional Disparities in China?" Journal of Comparative Economics, 29 (1). 
Démurger, Sylvie, (2000) "Economic Opening and Growth in China" Paris: OECD Development Centre Studies.

Dholakia, R (1994). "Spatial Dimension of Acceleration of Economic Growth in India", Economic and Political Weekly, Vol. XXIX, No. 35, August 21.

Dowrick, Steve and Duc-Tho Nguyen (1989). "OECD Comparative Economic growth 1950-85: Catch-Up and Convergence". American Economic Review, 79(5), pp. 1010-30.

Economic Survey, 1994-95, Ministry of Finance, Government of India.

Estimates of State Domestic Product, Central Statistical Organization, Department of Statistics, Government of India, various issues.

Economic and Political Weekly Research Foundation (1998). "National Accounts Statistics of India 195051 to $1996-97 "$ ".

Gupta S. (1973). "The Role of the Public Sector in Reducing Regional Income Disparity in India", Journal of Development Studies, Vol. 9, No. 2, pp. 243-60.

India Database: The Economy, (1990) Annual Time Series Data, Volume I and II, H L Chandok and The Policy Group.

Jian, Tianlun, Jeffrey D. Sachs and Andrew Warner (1995). "Trends in Regional Inequality in China, Development Discussion Paper No., 518, Harvard Institute for International Development.

Kalwajit Singh (1997). Corpwatch (on the web) "MNC Masala", August. http://www.corpwatch.org/trac/feature/india/globalization/orissa.html

King, E. M., D. Filmer, L. Pritchett, (1998) "Gender Disparity in South Asia: Comparisons between and within Countries", Washington, D. C: The World Bank.

Kurian, N.J., (2000). "Widening Regional Disparities in India - Some Indicators", Economic and Political Weekly, Vol. XXXV, No. 7, February 12-18.

Majumdar, Grace and J L Kapoor, (1980). "Behavior of inter-state income inequalities in India". Paper presented at the Twelfth Conference of the Indian Association for Research on National Income and Wealth.

Nair, K R G (1971). "A Note on Inter-State Income Differentials in India 1950-51 to 1960-61", Journal of Development Studies, Vol. 7, No 1, pp. 441-47.

Radhakrishna, R. (2002). "Agricultural Growth, Employment and Poverty: A Policy Perspective," Economic and Political Weekly, January 19, Vol. XXXVII, No. 3.

Raiser, Martin, (1998) "Subsidising Inequality: Economic Reforms, Fiscal Transfers and Convergence across Chinese Provinces.” Journal of Development Studies 34, 3:1-26.

Rao, M.G., R.T. Shand, and K. P. Kalirajan (1999) "Convergence of Incomes Across Indian States - A Divergent View", Economic and Political Weekly, Vol. XXXIV, No. 13, March 27.

Reserve Bank of India Bulletin (Feb 1999)

Romer, Paul M. (1986) "Increasing Returns and Long-Run Growth", Journal of Political Economy, 94(5), pp. 1002-37. 
Sarkar, P.C. (1994). "Regional Imbalances in Indian Economy over Plan Periods", Economic and Political Weekly, Vol. XXIX, No. 2, March 12.

Sachs, Jeffrey and Andrew Warner (1995). "Economic Reform and the Process of Global Integration," Brookings Papers on Economic Activity, No. 1, pp. 1-118.

Subrahmanian, K.K. (1990) "Development Paradox in Kerala, Analysis of Industrial Stagnation", Economic and Political Weekly September 15.

Statistical Abstract, Department of Statistics, Government of India, various issues.

Tirtha, Ranjit (2000). Geography of India. Jaipur and New Delhi: Rawat Publications

William, Jeffrey, G. (1965). "Regional Inequality and the Process of National Development", Economic Development and Cultural Change, Vol. 13, No. 4, Part II. 


\section{APPENDIX}

\section{Data sources and description:}

Our data covers the period 1980-98 in fourteen major states of India. Those not included are Arunachal Pradesh, Assam, Chattisgarh, Delhi, Goa, Himachal Pradesh, Jharkhand, Meghalaya, Mizoram, Nagaland, Pondicherry, Uttaranchal, Sikkim. Data is not available for these states over a large number of years. The data used in the paper for analyzing income convergence or divergence among Indian states is from Indian official statistical publications. Various volumes of the Central Statistical Organization (CSO) publication on Estimates of State Domestic Product were used. The concept of SDP used in the paper is the state domestic product (SDP) that is based on income originating in the state rather than income accruing to the state.

The primary sector consists of agriculture and allied activities, fishery, forestry, and mining and quarrying sub-sectors. The secondary sector includes manufacturing, construction, electricity, gas and water supply. The tertiary sector comprises transport, communication, storage, hotel and restaurants, finance and real estate, banking and insurance, public administration, community and personal services, and other services. We have used the share of primary sector in the SDP to measure the change in the economic structure and its effect on growth. By total population we mean the total number of people in the state as of the end of a particular year. CSO data on state-wise real capita SDP is arrived at by using total population along with SDP deflated by the base year prices.

Some of the data are from the Sample Registration System of the Registrar General, India. SRS is a large-scale demographic sample survey for providing reliable annual estimates of birth rate, death rate and other fertility and mortality indicators at state and national levels and also for rural and urban levels separately. By being able to analyzing age-specific mortality rates, SRS data also facilitate the construction of life tables at birth and at selected ages for the above disaggregated categories including those for males and females separately. The age composition of the population from two successive censuses provides a base for the construction of decadal life tables, but the SRS alone provides trends in life expectancy at more frequent intervals, in fact in recent years on an annual basis.

SRS uses the mechanism of a dual record system for collection of data. First, continuous enumeration of births and deaths is undertaken by a part-time but resident enumerator and second, an independent retrospective survey every six months is done by a computer supervisor. The data so obtained through these two processes are matched. The unmatched and partially matched events are reverified in the field and thereafter an unduplicated count of births and deaths is obtained. The advantage of this procedure is said to be that, in addition to elimination of errors of duplication, it leads to a quantitative assessment of sources of distortion in the two sets of records making it a self-evaluating technique. The procedure, in other words, is said to ensure a crosscheck on the correctness and completeness of the data collected. SRS was introduced in 1969-1970 as the absence of dependable data from the Civil Registration System (CRS) began to be felt in the middle of the 1960's.

Data on the level of investment in individual states, comparable with the investment data at the national level obtained from the national accounts are simply not available.

\section{Technical Appendix:}

$\mathrm{x}_{\mathrm{i}}$ is the $\log$ of real GSDP per capita. There are 14 states $(\mathrm{N}=14) ; 8$ of which are in Group I $\left(\mathrm{n}_{1}=8\right)$ and 6 of which are in Group II $\left(\mathrm{n}_{2}=6\right)$. Variance is calculated as follows:

$$
\operatorname{Var}\left(x_{i}\right)=\frac{1}{N-1} \sum_{1}^{N}\left(x_{i}-\bar{x}\right)^{2}=\frac{1}{N-1}\left(\sum_{1}^{n_{1}}\left(x_{i}-\bar{x}\right)^{2}+\sum_{n_{2}+1}^{N}\left(x_{i}-\bar{x}\right)^{2}\right)
$$


We proceed to add and subtract the means within Group I and Group II, denoted respectively, $\mathrm{x}_{1}$ and $\mathrm{x}_{2}$. Some of the terms disappear because the sum of the deviations from the mean is zero, leaving us with:

$$
=\frac{1}{N-1}\left(\sum_{1}^{n_{1}}\left(x_{i}-\overline{x_{1}}\right)^{2}+\sum_{1}^{n_{1}}\left(\overline{x_{1}}-\bar{x}\right)^{2}+\sum_{n_{2}}^{N}\left(x_{i}-\overline{x_{2}}\right)^{2}+\sum_{n_{2}}^{N}\left(\overline{x_{2}}-\bar{x}\right)^{2}\right) \text {. }
$$

This simplifies to:

$$
\frac{\left(n_{1}-1\right)}{N-1} \operatorname{Var}\left(x_{1 i}\right)+\frac{\left(n_{2}-1\right)}{N-1} \operatorname{Var}\left(x_{2 i}\right)+\frac{n_{1}\left(N-n_{1}\right)^{2}+n_{2}\left(N-n_{2}\right)^{2}}{(N-1) N^{2}} \operatorname{Var}\left(x_{i}-\bar{x}\right)^{2} .
$$

In our sample, the constants yield an equation of the form:

$$
\text { 0.538Var(Group I) + 0.385Var(Group II) + 0.264Var(Average Between Groups). }
$$

Source: Jian, Tianlun, Jeffrey D. Sachs and Andrew Warner (1995). 
Figure 1: Major States of India

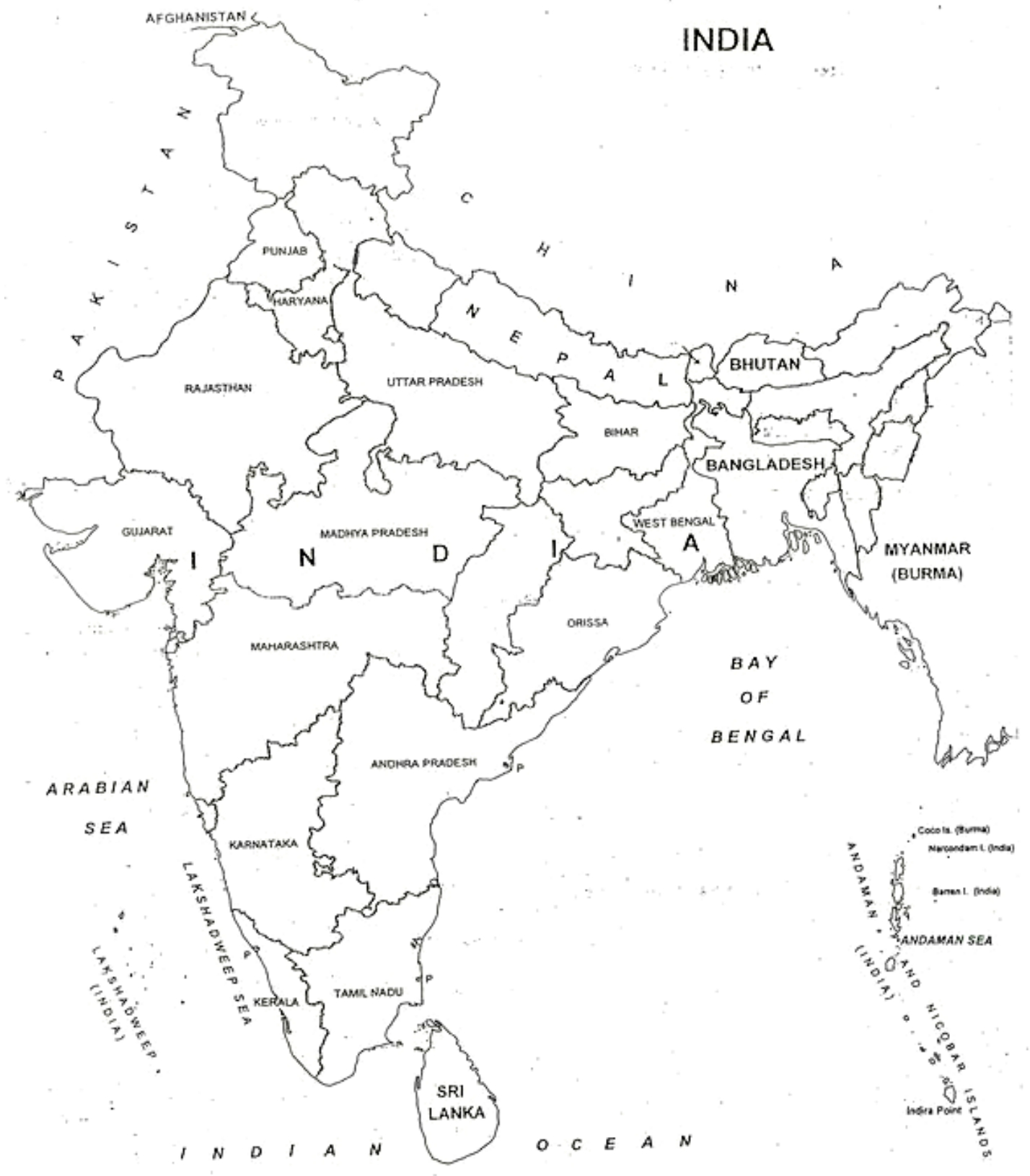


Table 1. Indian States: Main Characteristics

\begin{tabular}{|c|c|c|c|c|c|c|c|}
\hline & $\begin{array}{l}\text { Gross } \\
\text { State } \\
\text { Domestic } \\
\text { Product } \\
\text { Per } \\
\text { Capita, } \\
1997 / 8 \\
\text { (Rupees } \\
\text { per } \\
\text { month) }\end{array}$ & $\begin{array}{l}\text { Growth in } \\
\text { GSDP } \\
\text { Capita, } \\
1980-98\end{array}$ & $\begin{array}{l}\text { Coastal } \\
\text { Access } \\
(\% \text { of } \\
\text { population } \\
\text { within } \\
100 \mathrm{~km} \text { of } \\
\text { coast })\end{array}$ & $\begin{array}{l}\text { Main } \\
\text { Climate } \\
\text { Zone: } \\
\text { Tropical }\end{array}$ & Arid & $\begin{array}{l}\text { Sub- } \\
\text { Tropical }\end{array}$ & $\begin{array}{l}\text { Major Port } \\
\text { City } \\
\text { (population } \\
\text { Greater } \\
\text { than } \\
5 \text { million) }\end{array}$ \\
\hline Andhra Pradesh & 2521 & 2.9 & 42 & 54 & 45 & 1 & \\
\hline Bihar & 1261 & 1.0 & 0 & 5 & 0 & 95 & \\
\hline Gujarat & 4505 & 4.3 & 71 & 17 & 82 & 0 & \\
\hline Haryana & 4516 & 3.1 & 0 & 0 & 87 & 13 & \\
\hline Karnataka & 3109 & 3.6 & 19 & 40 & 60 & 0 & \\
\hline Kerala & 2823 & 3.1 & 1.0 & 1 & 0 & 0 & \\
\hline Madhya Pradesh & 2286 & 2.5 & 0 & 35 & 9 & 56 & \\
\hline Maharashtra & 5690 & 4.5 & 34 & 61 & 39 & 0 & Mumbai \\
\hline Orissa & 1871 & 1.7 & 56 & 67 & 0 & 33 & \\
\hline Punjab & 5079 & 3.0 & 0 & 0 & 76 & 24 & \\
\hline Rajasthan & 2621 & 3.8 & 0 & 7 & 80 & 13 & \\
\hline Tamil Nadu & 3454 & 4.3 & 65 & 96 & 4 & 0 & Chennai \\
\hline Uttar Pradesh & 2023 & 2.0 & 0 & 5 & 8 & 82 & \\
\hline West Bengal & 3308 & 3.3 & 43 & 67 & 0 & 33 & Kolkata \\
\hline
\end{tabular}


Table 2. 14 Indian states ranked according to GSDP per capita levels (highest income $=1$, lowest income $=14)$

\begin{tabular}{|l|l|l|l|l|}
\hline & $\mathbf{1 9 8 0 - 8 1}$ & $\mathbf{1 9 9 1 - 9 2}$ & $\mathbf{1 9 9 6 - 9 7}$ & $\mathbf{1 9 9 8 - 1 9 9 9}$ \\
\hline $\mathbf{1}$ & Punjab & Punjab & Maharashtra & Maharashtra \\
\hline $\mathbf{2}$ & Maharashtra & Haryana & Punjab & Punjab \\
\hline $\mathbf{3}$ & Haryana & Maharashtra & Haryana & Gujarat \\
\hline $\mathbf{4}$ & Gujarat & Gujarat & Gujarat & Haryana \\
\hline $\mathbf{5}$ & West Bengal & Tamil Nadu & Tamil Nadu & Tamil Nadu \\
\hline $\mathbf{6}$ & Kerala & Karanataka & West Bengal & West Bengal \\
\hline $\mathbf{7}$ & Karnataka & West Bengal & Karnataka & Karnataka \\
\hline $\mathbf{8}$ & Tamil Nadu & Kerala & Kerala & Kerala \\
\hline $\mathbf{9}$ & Andhra Pradesh & Andhra Pradesh & Rajasthan & Rajasthan \\
\hline $\mathbf{1 0}$ & Madhya Pradesh & Rajasthan & Andhra Pradesh & Andhra Pradesh \\
\hline $\mathbf{1 1}$ & Uttar Pradesh & Uttar Pradesh & Madhya Pradesh & Madhya Pradesh \\
\hline $\mathbf{1 2}$ & Orissa & Madhya Pradesh & Uttar Pradesh & Uttar Pradesh \\
\hline $\mathbf{1 3}$ & Rajasthan & Orissa & Orissa & Orissa \\
\hline $\mathbf{1 4}$ & Bihar & Bihar & Bihar & Bihar \\
\hline
\end{tabular}


Table 3. $\beta$-convergence Regressions (Dependent Variable: Growth rate)

\begin{tabular}{|c|c|c|c|}
\hline & $\mathbf{1 9 8 0 - 9 8}$ & $\mathbf{1 9 8 0 - 1 9 9 0}$ & $\mathbf{1 9 9 1 - 1 9 9 8}$ \\
\hline $\begin{array}{c}\text { Log of Initial per Capita real } \\
\text { GSDP (All) }\end{array}$ & $2.0(2.54)$ & $1.23(1.09)$ & $2.91(1.91)$ \\
\hline $\begin{array}{c}\text { Log of Initial per Capita real } \\
\text { GSDP (GrI) }\end{array}$ & $-0.2(0.18)$ & $1.32(0.86)$ & $9.34(3.47)$ \\
\hline $\begin{array}{c}\text { Log of Initial per Capita real } \\
\text { GSDP (GrII) }\end{array}$ & $4.4(1.51)$ & $-0.66(0.11)$ & $-1.74(0.62)$ \\
\hline
\end{tabular}


Table 4. Rates of growth of per capita GSDP

\begin{tabular}{|c|c|c|c|}
\hline $\begin{array}{l}\text { State (ranked from highest } \\
\text { income in } 1980 / 1 \text { ) }\end{array}$ & $1980-81$ to $1990-91$ & $\begin{array}{c}\text { State (ranked from } \\
\text { highest income in } \\
1990 / 1)\end{array}$ & $1992-93$ to $1998-99$ \\
\hline Punjab & 3.8 & Punjab & 2.8 \\
\hline Maharashtra & 4.3 & Haryana & 2.6 \\
\hline Haryana & 4.6 & Maharashtra & 6.8 \\
\hline Gujarat & 3.8 & Gujarat & 7.8 \\
\hline West Bengal & 2.3 & Tamil Nadu & 5.0 \\
\hline Kerala & 2.5 & Karnataka & 3.5 \\
\hline Karnataka & 3.6 & West Bengal & 4.8 \\
\hline Tamil Nadu & 5.0 & Kerala & 4.6 \\
\hline Andhra Pradesh & 2.9 & Andhra Pradesh & 3.7 \\
\hline Madhya Pradesh & 2.9 & Rajasthan & 4.4 \\
\hline Uttar Pradesh & 3.0 & Uttar Pradesh & 1.6 \\
\hline Orissa & 1.0 & Madhya Pradesh & 3.9 \\
\hline Rajasthan & 5.8 & Orissa & 1.6 \\
\hline Bihar & 2.9 & Bihar & -0.2 \\
\hline Unweighted Average & 3.5 & Unweighted average & 3.8 \\
\hline
\end{tabular}


Table 5. Variance Decomposition Within and Between Group I and Group II States

\begin{tabular}{|r|r|r|r|r|}
\hline & Within Group I & Within Group II & $\begin{array}{c}\text { Between Group I } \\
\text { and Group II }\end{array}$ & Overall Variance \\
\hline $\mathbf{1 9 8 0}$ & 0.005759 & 0.001312 & 0.001868 & 0.008939 \\
\hline $\mathbf{1 9 8 1}$ & 0.006176 & 0.001624 & 0.00206 & 0.00986 \\
\hline $\mathbf{1 9 8 2}$ & 0.006715 & 0.001852 & 0.002263 & 0.01083 \\
\hline $\mathbf{1 9 8 3}$ & 0.006826 & 0.001618 & 0.00223 & 0.010674 \\
\hline $\mathbf{1 9 8 4}$ & 0.006076 & 0.000838 & 0.001827 & 0.008741 \\
\hline $\mathbf{1 9 8 5}$ & 0.007649 & 0.000964 & 0.002275 & 0.010888 \\
\hline $\mathbf{1 9 8 6}$ & 0.007475 & 0.000601 & 0.002134 & 0.01021 \\
\hline $\mathbf{1 9 8 7}$ & 0.006986 & 0.001246 & 0.002175 & 0.010407 \\
\hline $\mathbf{1 9 8 8}$ & 0.007654 & 0.001578 & 0.002439 & 0.011671 \\
\hline $\mathbf{1 9 8 9}$ & 0.007842 & 0.001842 & 0.002558 & 0.012242 \\
\hline $\mathbf{1 9 9 0}$ & 0.007443 & 0.002135 & 0.00253 & 0.012108 \\
\hline $\mathbf{1 9 9 1}$ & 0.006607 & 0.001944 & 0.002258 & 0.010809 \\
\hline $\mathbf{1 9 9 2}$ & 0.006977 & 0.003196 & 0.002687 & 0.01286 \\
\hline $\mathbf{1 9 9 3}$ & 0.006235 & 0.003072 & 0.002458 & 0.011765 \\
\hline $\mathbf{1 9 9 4}$ & 0.006243 & 0.003741 & 0.002636 & 0.01262 \\
\hline $\mathbf{1 9 9 5}$ & 0.006064 & 0.004273 & 0.002729 & 0.013066 \\
\hline $\mathbf{1 9 9 6}$ & 0.00648 & 0.004876 & 0.002998 & 0.014354 \\
\hline $\mathbf{1 9 9 7}$ & 0.00654 & 0.005225 & 0.003106 & 0.014871 \\
\hline $\mathbf{1 9 9 8}$ & 0.006637 & 0.005593 & 0.003229 & 0.015459 \\
\hline
\end{tabular}


Table 6. Some Regional Factors in Sectoral Growth

\begin{tabular}{|c|c|c|c|c|}
\hline & $\begin{array}{l}\text { Key Determinants } \\
\text { for future growth }\end{array}$ & Favored States & Time Period & $\begin{array}{l}\text { Current } \\
\text { contribution to } \\
\text { growth }\end{array}$ \\
\hline Agriculture & $\begin{array}{l}\text { Climate, } \\
\text { agricultural } \\
\text { technologies }\end{array}$ & $\begin{array}{l}\text { Punjab, } \\
\text { Haryana }\end{array}$ & $\begin{array}{l}\text { Green Revolution, } \\
1970 \text { s-1980s }\end{array}$ & Low \\
\hline Manufacturing & $\begin{array}{l}\text { Urban, coastal, } \\
\text { major port } \\
\text { facilities, attracting } \\
\text { foreign direct } \\
\text { investment }\end{array}$ & $\begin{array}{l}\text { Maharashtra, West } \\
\text { Bengal, Tamil } \\
\text { Nadu, Gujarat }\end{array}$ & $\begin{array}{l}\text { 1980s onward, } \\
\text { with rising } \\
\text { importance in the } \\
\text { 1990s }\end{array}$ & High \\
\hline Tourism & $\begin{array}{l}\text { Historical, cultural, } \\
\text { and natural } \\
\text { attractions, } \\
\text { proximity to major } \\
\text { ports of entry such } \\
\text { as Delhi and } \\
\text { Mumbai }\end{array}$ & $\begin{array}{l}\text { Rajasthan, } \\
\text { Maharashtra }\end{array}$ & 1980s onward & Moderate \\
\hline $\begin{array}{l}\text { High-tech Services } \\
\text { (finance and ICT) }\end{array}$ & $\begin{array}{l}\text { Urban, skilled } \\
\text { labor force, } \\
\text { universities }\end{array}$ & $\begin{array}{l}\text { Maharashtra, } \\
\text { Tamil Nadu, } \\
\text { Karnataka, West } \\
\text { Bengal }\end{array}$ & 1990s & High \\
\hline
\end{tabular}


Table 7. Distribution of 100\% Export Oriented Units (EOUs) (August 1991-May 2001)

\begin{tabular}{|l|c|c|c|}
\hline \multicolumn{1}{|c|}{ State/UT } & Number of Units & \% of Total EOUs & $\begin{array}{c}\text { EOUs per million } \\
\text { population (2001) }\end{array}$ \\
\hline Andhra Pradesh & 404 & 10.96 & 5.3 \\
\hline Bihar & 7 & 0.19 & 0.1 \\
\hline Gujarat & 458 & 12.43 & 9.1 \\
\hline Haryana & 206 & 5.59 & 9.8 \\
\hline Karnataka & 376 & 10.20 & 2.1 \\
\hline Kerala & 72 & 1.95 & 2.3 \\
\hline Madhya Pradesh & 136 & 3.69 & 5.8 \\
\hline Maharashtra & 563 & 15.28 & 1.1 \\
\hline Orissa & 41 & 1.11 & 5.2 \\
\hline Punjab & 127 & 3.45 & 3.6 \\
\hline Rajasthan & 205 & 5.56 & 8.8 \\
\hline Tamil Nadu & 547 & 14.84 & 1.2 \\
\hline Uttar Pradesh & 206 & 5.59 & 1.2 \\
\hline West Bengal & 98 & 2.66 & $G 01$ \\
\hline Sourc Sectar|
\end{tabular}

Source: Secretariat for Industrial Approvals (SIA) Newsletter, June 2001, Minister of Industry, GOI 
Table 8. Software Exports by State, 1995-96 (Rs. Millions)

\begin{tabular}{|l|c|c|}
\hline State & Value of Software Exports & Software Exports per capita \\
\hline Andhra Pradesh & 931.3 & 12.9 \\
\hline Bihar & -- & -- \\
\hline Gujarat & 55.1 & 1.2 \\
\hline Haryana & 629.9 & 34.7 \\
\hline Karnataka & 7278.4 & 150.9 \\
\hline Kerala & 38.7 & 0.0 \\
\hline Madhya Pradesh & 2.5 & 82.1 \\
\hline Maharashtra & 7085.4 & -- \\
\hline Orissa & -- & 0.4 \\
\hline Punjab & 9.0 & -- \\
\hline Rajasthan & -- & 53.3 \\
\hline Tamil Nadu & 3116.7 & -- \\
\hline Uttar Pradesh & -- & \\
\hline Source: WWW & 1.2 & \\
\hline
\end{tabular}

Source: WWW Page: http://www.maharashtra.gov.in/english/invest/softw.htm, current as of 4 April 1999 
Table 9. FDI Flows

Source: Secretariat for Industrial Approvals (SIA) Newsletter, August 2001, Minister of Industry, GOI

\begin{tabular}{|l|l|l|}
\hline \multirow{2}{*}{ States } & \multicolumn{2}{|l|}{$\begin{array}{l}\text { Foreign Direct Investment } \\
\text { Approved } \\
\text { July 2001) }\end{array}$} \\
\cline { 2 - 3 } & $\begin{array}{l}\text { Invest- } \\
\text { ment } \\
\text { (Rs. ing } \\
\text { Millions) }\end{array}$ & $\begin{array}{l}\text { FDI per capita } \\
\text { (1991-01 per } \\
\text { Pop1 } \\
\text { Population) }\end{array}$ \\
\hline Andhra Pradesh & 124701.31 & 1646 \\
\hline Bihar & 7395.28 & 89 \\
\hline Gujarat & 168555.48 & 3331 \\
\hline Haryana & 31947.46 & 1515 \\
\hline Karnataka & 208156.32 & 3947 \\
\hline Kerala & 14360.83 & 451 \\
\hline Madhya Pradesh & 91542.20 & 1515 \\
\hline Maharashtra & 456286.23 & 4716 \\
\hline Orissa & 82289.14 & 2241 \\
\hline Punjab & 19519.22 & 803 \\
\hline Rajasthan & 25916.69 & 459 \\
\hline Tamil Nadu & 222804.00 & 3587 \\
\hline Uttar Pradesh & 42047.76 & 253 \\
\hline West Bengal & 84234.59 & 1050 \\
\hline & & \\
\hline
\end{tabular}


Table 10. Rates of Urbanization

\begin{tabular}{|c|c|c|c|}
\hline & 1971 & 1981 & 1991 \\
\hline Andhra Pradesh & $19.3(7)$ & $23.32(7)$ & $26.84(7)$ \\
\hline Bihar & $10.0(13)$ & $12.47(13)$ & $13.17(14)$ \\
\hline Gujarat & $28.1(3)$ & $31.10(3)$ & $34.40(2)$ \\
\hline Haryana & $17.7(8)$ & $21.88(8)$ & $24.79(9)$ \\
\hline Karnataka & $24.3(5)$ & $28.89(4)$ & $30.91(4)$ \\
\hline Kerala & $16.2(11)$ & $18.74(11)$ & $26.44(8)$ \\
\hline Madhya Pradesh & $16.3(10)$ & $20.29(10)$ & $23.21(10)$ \\
\hline Maharashtra & $31.2(1)$ & $35.03(1)$ & $38.73(1)$ \\
\hline Orissa & $8.4(14)$ & $11.79(14)$ & $13.43(13)$ \\
\hline Punjab & $23.7(6)$ & $27.68(5)$ & $29.72(5)$ \\
\hline Rajasthan & $17.6(9)$ & $21.05(9)$ & $22.88(11)$ \\
\hline Tamil Nadu & $30.3(2)$ & $32.95(2)$ & $34.20(3)$ \\
\hline Uttar Pradesh & $14.0(12)$ & $17.95(12)$ & $19.89(12)$ \\
\hline West Bengal & $24.8(4)$ & $26.47(6)$ & $27.39(6)$ \\
\hline
\end{tabular}


Table 11. Growth Equations, 1980-98

\begin{tabular}{|l|l|l|l|l|l|l|}
\hline Regression & 1 & 2 & 3 & 4 & 5 & 6 \\
\hline Period & $1980-98$ & $1980-98$ & $1980-90$ & $1991-98$ & $1991-98$ & $1991-98$ \\
\hline & & & & & & \\
\hline Ln(initial & -0.04 & & -4.68 & 0.08 & -1.83 & \\
income) & $(0.08)$ & & $(3.29)$ & $(0.02)$ & $(1.35)$ & \\
\hline Urbanization & 0.13 & 0.13 & 0.19 & 0.25 & 0.30 & 0.23 \\
& $(5.30)$ & $(7.31)$ & $(5.30)$ & $(2.09)$ & $(4.75)$ & $(5.38)$ \\
\hline $\begin{array}{l}\text { Green } \\
\text { Revolution }\end{array}$ & & $\begin{array}{l}3.54 \\
(4.01)\end{array}$ & -1.27 & $(0.48)$ & & \\
\hline Rajasthan & & 1.56 & 1.61 & & \\
Dummy & & & $(2.43)$ & $(1.24)$ & & \\
\hline Constant & 0.39 & 0.05 & 33.17 & -3.29 & 10.25 & -2.33 \\
& $(0.09)$ & $(0.12)$ & $(3.37)$ & $(0.12)$ & $(1.09)$ & $(1.98)$ \\
\hline & & & & & & \\
\hline$R^{2}$ & 0.82 & 0.82 & 0.88 & 0.79 & 0.75 & 0.71 \\
\hline
\end{tabular}

(t-statistics in parentheses)

Note that for the equations beginning in 1980, urbanization in 1981 is used; for the regressions beginning in 1991, urbanization in 1991 is used. 
Table 12. Ratio of Urban to Rural Expenditures, 1987-88 and 1999-2000 (Total expenditures)

$\begin{array}{lrrr}\text { State } & \text { TEU/R 87-88 } & \text { TEU/R 99-00 } & \text { \% change } \\ & & & \\ \text { Andhra Pradesh } & 1.438081559 & 1.705253412 & 18.57835191 \\ \text { Bihar } & 1.365453614 & 1.562970657 & 14.465306 \\ \text { Gujarat } & 1.492866005 & 1.617325377 & 8.336941925 \\ \text { Haryana } & 1.172831454 & 1.27674347 & 8.859927407 \\ \text { Karnataka } & 1.493864414 & 1.822782024 & 22.01790253 \\ \text { Kerala } & 1.258901972 & 1.217980698 & -3.250552876 \\ \text { Madhya Pradesh } & 1.66206508 & 1.727422167 & 3.93228208 \\ \text { Maharashtra } & 1.73869503 & 1.959317189 & 12.68895091 \\ \text { Orissa } & 1.766135989 & 1.657394753 & -6.157013782 \\ \text { Punjab } & 1.105491625 & 1.210010501 & 9.454515326 \\ \text { Rajasthan } & 1.337550607 & 1.449879755 & 8.398123199 \\ \text { Tamil Nadu } & 1.612482987 & 1.890073336 & 17.21508705 \\ \text { Uttar Pradesh } & 1.457792426 & 1.47939481 & 1.481855923 \\ \text { West Bengal } & 1.664442517 & 1.905430959 & 14.47862809 \\ \text { ALL India } & 1.580834915 & 1.758515715 & 11.23968093\end{array}$

TEU/R -- Total expenditure urban-rural ratio

Source: For 1987/88 the data is from Sarvekshana, Vol.XV, No. 1, Issue No. 48, July-September 1991, National Sample Survey Organization, Department of Statistics, Ministry of Planning, Gol. For 1999/00, the data is from NSS Report No. 457, May 2001. 
Table 13. Percentage of Villages Electrified

\begin{tabular}{|l|c|c|c|}
\hline & $\mathbf{1 9 8 5}$ & $\mathbf{1 9 9 8}$ & Change \\
\hline Andhra Pradesh & 83.95 & 97.03 & 13.08 \\
\hline Bihar & 49.63 & 70.82 & 1.19 \\
\hline Gujarat & 88.26 & 99.02 & 0 \\
\hline Haryana & 100.00 & 100.00 & 15.51 \\
\hline Karnataka & 83.14 & 98.65 & 0 \\
\hline Kerala & 100.00 & 100.00 & 38.14 \\
\hline Madhya Pradesh & 57.10 & 95.24 & 7.16 \\
\hline Maharashtra & 92.84 & 100.00 & 0.51 \\
\hline Orissa & 50.48 & 72.23 & 38.47 \\
\hline Punjab & 99.49 & 100.00 & 0.21 \\
\hline Rajasthan & 59.48 & 97.95 & 22.08 \\
\hline Tamil Nadu & 99.73 & 99.94 & 26.68 \\
\hline Uttar Pradesh & 56.03 & 78.11 & 22.65 \\
\hline West Bengal & 50.43 & 77.11 & 0.75 \\
\hline All India & 64.02 & 86.67 & 1098 \\
\hline Source: & & & \\
\hline
\end{tabular}

Source: 1985 data from Seventh Five Year Plan (1985-90), Planning Commission, GOI, p.164 and 1998 data from Economic and Political Weekly, January 13, 2001 
Table 14. Proximity of Population to the Coast

\begin{tabular}{|l|l|l|}
\hline Region & $\begin{array}{l}\text { Population within 100 km of } \\
\text { the coast }\end{array}$ & $\begin{array}{l}\text { Population within 100 km of } \\
\text { the coast or sea-navigable } \\
\text { waterway }\end{array}$ \\
\hline India & 22 & 38 \\
\hline China & & \\
\hline Japan & 19 & 45 \\
\hline United States & 97 & 97 \\
\hline European Union (EU 15) & 35 & 65 \\
\hline
\end{tabular}

Source: CID Geography Database (2001) 
Table 15. Percent of Population in Ecozones

\begin{tabular}{|l|l|l|l|l|l|}
\hline & $\begin{array}{l}\text { Tropical } \\
(\mathrm{Aw}+\mathrm{Am})\end{array}$ & $\begin{array}{l}\text { Sub-Tropical } \\
(\mathrm{Cw})\end{array}$ & Arid (Bs+Bw) & $\begin{array}{l}\text { Temperate } \\
(\mathrm{Cf}+\mathrm{Cs}+\mathrm{Dw}+\mathrm{Df}+ \\
\mathrm{E})\end{array}$ & Highland (H) \\
\hline India & 33 & 32 & 28 & 0 & 7 \\
\hline & & & & & 24 \\
\hline China & 0 & 10 & 36 & 30 & 0 \\
\hline Japan & 0 & 0 & 0 & 1 & 10 \\
\hline United States & 0 & 0 & 19 & 70 & 1 \\
\hline $\begin{array}{l}\text { European } \\
\text { Union (15) }\end{array}$ & 0 & 0 & 1 & 98 & \\
\hline
\end{tabular}

Source: CID Geography Database, using Koeppen-Geiger climate classification 
Table 16. Infant Mortality Rate (Deaths under Age 1 per 1,000 live births)

\begin{tabular}{|l|l|l|}
\hline State & $\mathbf{1 9 9 0}$ & $\mathbf{1 9 9 8}$ \\
\hline Andhra Pradesh & 71 & 66 \\
\hline Bihar & 71 & 67 \\
\hline Gujarat & 69 & 64 \\
\hline Haryana & 71 & 70 \\
\hline Karnataka & 73 & 58 \\
\hline Kerala & 17 & 16 \\
\hline Madhya Pradesh & 111 & 98 \\
\hline Maharashtra & 59 & 49 \\
\hline Orissa & 120 & 98 \\
\hline Punjab & 57 & 54 \\
\hline Rajasthan & 84 & 83 \\
\hline Tamil Nadu & 58 & 53 \\
\hline Uttar Pradesh & 98 & 85 \\
\hline West Bengal & 66 & 53 \\
\hline
\end{tabular}

Source: EPW Research Foundation 
Table 17. Life Expectancy at Birth (Years)

\begin{tabular}{|l|c|c|}
\hline State & $\mathbf{1 9 8 1}$ & $\mathbf{1 9 9 3}$ \\
\hline Andhra Pradesh & 59.8 & 62.8 \\
\hline Bihar & 51.5 & 58 \\
\hline Gujarat & 59.3 & 62 \\
\hline Haryana & 59 & 64 \\
\hline Karnataka & 62 & 63.9 \\
\hline Kerala & 71.5 & 75.6 \\
\hline Madhya Pradesh & 51.9 & 54.6 \\
\hline Maharashtra & 62.1 & 65.8 \\
\hline Orissa & 53 & 56.2 \\
\hline Punjab & 63.6 & 68.4 \\
\hline Rajasthan & 53.8 & 59.4 \\
\hline Tamil Nadu & 57.4 & 64.4 \\
\hline Uttar Pradesh & 48.5 & 56 \\
\hline West Bengal & 58 & 62.8 \\
\hline All India & 59.8 & 62.8 \\
\hline
\end{tabular}

Source: Health Information of India, Central Bureau of Health Intelligence, Ministry of Health and Family Welfare, Government of India, 1994 
Figure 2. Standard Deviation of Log Real Per Capita GSDP

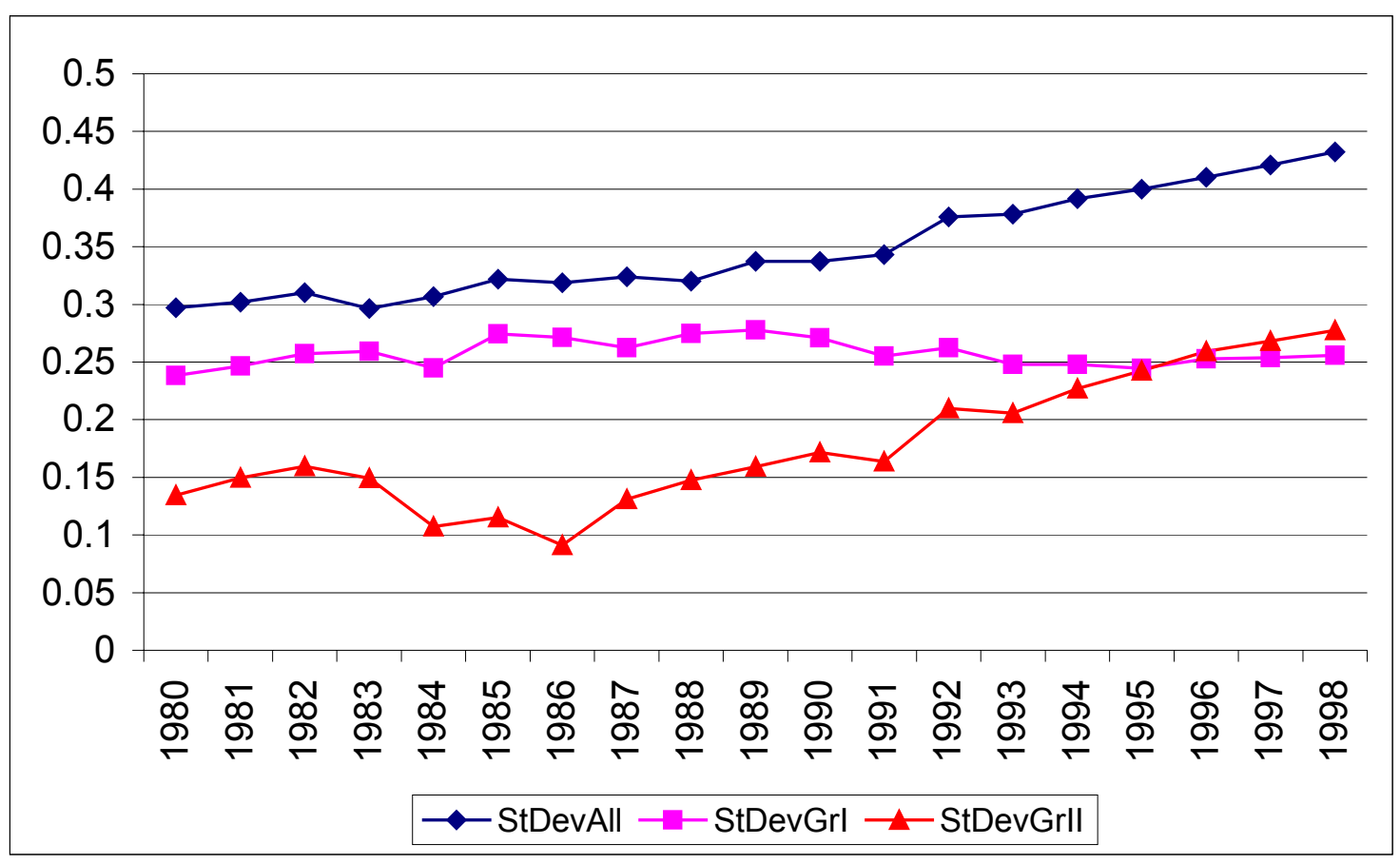


Figure 3. Relationship of Urbanization (1981) and Economic Growth (1980-98)

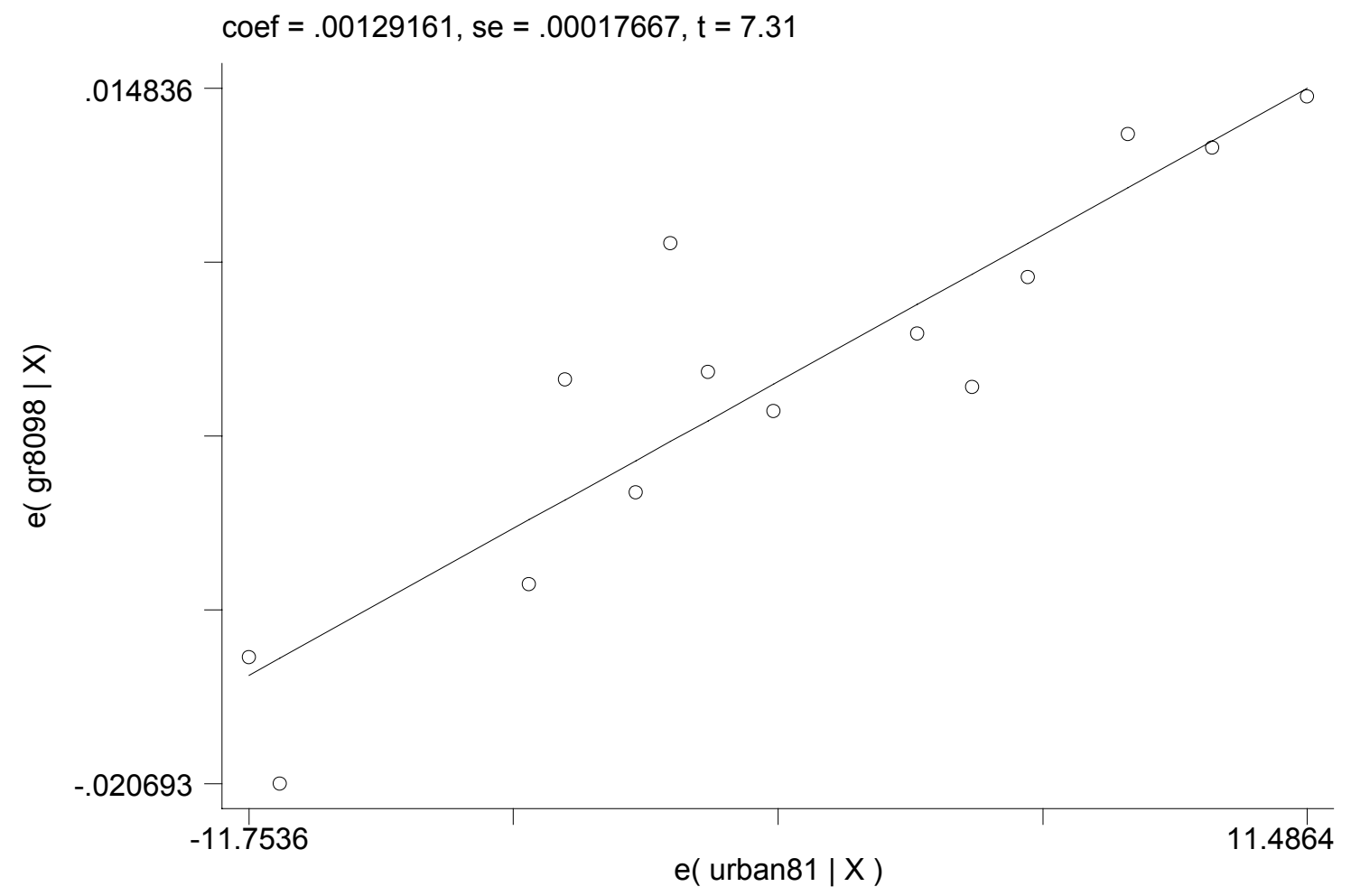

